\title{
ARTIKEL
}

\section{De Wet normering bezoldiging topfunctionarissen publieke en semipublieke sector (WNT): (in) werking}

\author{
L.G. Verburg
}

\section{Een korte inleidende terugblik}

Op 1 januari 2013 trad de Wet normering bezoldiging topfunctionarissen publieke en semipublieke sector (WNT) in werking. ${ }^{1}$ Deze bijdrage bevat een beschouwing over deze 'unieke' wet: het doel, de keuzes, de middelen en natuurlijk de vraag of de WNT bestand is tegen lieden die het beloningsspel niet (ruiterlijk) willen meespelen. Ook het regeerakkoord 'Bruggen slaan' van 29 oktober 2012 komt ter sprake. Zet men de over de bezoldiging in de publieke en semipublieke sector in dit akkoord opgenomen woorden om in daden, dan vormt de WNT slechts het eerste bedrijf van een langdurige(r) worsteling met de notie van een rechtvaardige bezoldiging in deze sectoren.

In 2002 stelde het kabinet de Adviescommissie Rechtspositie Politieke Ambtsdragers (commissie-Dijkstal) in. De commissie-Dijkstal bracht verspreid over een periode van zeven jaar zeven adviezen uit. In die zin waren deze jaren 'vet'. De zeven adviezen vormden de blauwdruk voor het topinkomensbeleid in de publieke en semipublieke sector. De regering besteedde ook zelf aandacht aan de inkomens van de topfunctionarissen in de publieke en semipublieke sectoren. Er waren debatten en de bestuurders werden opgeroepen de salarissen te matigen. De wetgever maakte in 2006 met de Wet openbaarmaking uit publieke middelen gefinancierde topinkomens (Wopt) de bezoldigingen die uitstegen boven het ministersalaris openbaar, met als primair doel de realisering van openheid en als

1 Wet van 15 november 2012, Stb. 2012, 583. Het Besluit houdende vaststelling van het tijdstip van inwerkingtreding dateert eveneens van 15 november 2012, Stb. 2012, 584. De WNT noopte tot aanpassing van de bezoldigingsbepalingen in de onderwijswetgeving. Het resultaat is te vinden in het eveneens op 1 januari 2013 in werking getreden Besluit van 10 december 2012 tot wijziging van verschillende algemene maatregelen van bestuur, Stb. 2012, 690. Zie voor eerdere beschouwingen over het thema van deze bijdrage H. Uhlenbroek, De Balkenende-norm; normering van topinkomens in de (semi)-publieke sector, ArbeidsRecht 2009/12, p. 54; M.S. Houwerzijl, Een wettelijk maximumloon voor topfunctionarissen in de (semi)publieke sector, in: W. Plessen, H. van Drongelen \& F. Hendrickx (red.), Sociaal Recht: tussen behoud en vernieuwing, Liber Amicorum voor prof. dr. Antoine Jacobs, Zutphen: Uitgeverij Paris 2011, p. 357-377; F.B.J. Grapperhaus, Over het ingrijpen in beloningen, TRA 2012/2, p. 13; M.C.T. Burgers, Wetsvoorstel WNT werpt haar schaduw vooruit, ArbeidsRecht 2012/36. 
nevendoelstelling het stimuleren van het publieke debat over topinkomens. ${ }^{2}$ De resultaten lieten niettemin te wensen over. ${ }^{3}$ Aan de conclusie tot wetgeving over te gaan lag (mede) ten grondslag dat de topfunctionarissen en hun werkgevers niet altijd blijk gaven van een op het punt van de bezoldiging noodzakelijke terughoudendheid. De bezoldigingen ontwikkelden zich, los van enkele uitschieters, weliswaar niet excessief, maar wel nam jaarlijks het aantal topfunctionarissen met een salaris dat hoger lag dan dat van een minister toe. ${ }^{4}$ Op zelfregulering viel niet te vertrouwen. ${ }^{5}$ In die zin waren deze jaren, in de visie van de wetgever, 'mager'.

Met het van 14 januari 2011 daterende wetsontwerp 32600 (ik spreek hierna in de tekst veelal over de WNT) zette het kabinet in op het normeren en maximeren van de topbezoldigingen in de publieke en semipublieke sector. ${ }^{6}$ Het doel was drieledig. De WNT moest voorzien in een democratisch gelegitimeerd instrument, gaf een afbakening van de instellingen die men tot de maatgevende sectoren rekent, en verhinderde dat deze instellingen rechtens in staat zijn bovenmatige bezoldigingen toe te kennen. ${ }^{7}$ De financiering uit publieke middelen vormde de rechtvaardiging voor de normering door de wetgever. ${ }^{8}$ Ik ondersteun de gedachte dat sprake is van een algemeen belang, mede in het licht van de geconstateerde stijgende lijn in de betrokken bezoldigingen en het feit dat de overheid zich het belang van matiging zichtbaar heeft aangetrokken. ${ }^{9}$

De memorie van toelichting (MvT) gaf aan dat het kabinet de hoofdregel hanteert dat de loonvorming in beginsel het primaat is van de sociale partners. De WNT

2 Wet openbaarmaking uit publieke middelen gefinancierde topinkomens (Wopt) van 9 februari 2006, Stb. 2006, 95. In 2009 vond een evaluatie plaats. Zie het advies van de commissie-Dijkstal, Gewopt en gewogen: evaluatie van de Wet openbaarmaking uit publieke middelen gefinancierde topinkomens (Wopt), bijlage bij Kamerstukken II 2008/09, 28 479, nr. 43. De Wopt is met de inwerkingtreding van de WNT per 1 januari 2013 ingetrokken.

3 Zo bleek uit een evaluatie van de codes bij woningcorporaties dat het gebrek aan naleving een gevolg was van het ontbreken van een wettelijke plicht daartoe. Zie Kamerstukken I 2011/12, 32 600 , nr. F, p. 8.

4 Kamerstukken I 2011/12, 32 600, nr. H, p. 9.

5 Kamerstukken II 2010/11, 32 600, nr. 3, p. 7-9.

6 Kamerstukken II 2008/09, 28 479, nr. 38.

7 Kamerstukken II 2010/11, 32 600, nr. 3, p. 6/7.

8 In die zin ook het advies van de Afdeling advisering van de Raad van State over het wetsvoorstel. Vgl. Kamerstukken I 2011/12, 32 600, nr. D, p. 5.

9 In 2008 overwoog ik dat de staat heeft te waken over de sociale samenhang en dat de waardering van de bezoldiging van de bestuurder in de maatschappij mede wordt bepaald door de mate waarin zijn inkomen wordt geaccepteerd als een aanvaardbare, immers proportionele, vergoeding voor zijn diensten. Ik had indertijd de bestuurders in de private sector op het netvlies. Deze overwegingen gelden a fortiori voor de topfunctionarissen in de (semi)publieke sector. Zie L.G. Verburg, De koers van de bestuurder (oratie Nijmegen; serie Onderneming en Recht, deel 45), Deventer: Kluwer 2008, p. 16-17. In dezelfde zin Beltzer in zijn annotatie bij Rb. Den Haag (vzr.) 11 januari 2013, JAR 2013/49 m.nt. Janssen (NVZD/Staat) in AR Updates, AR_2013_0024. Kritischer is Grapperhaus 2012, p. 13. 
vormt een (in de visie van de MvT eenmalige) uitzondering op deze regel: een topfunctionaris kan geen rechten ontlenen aan met de WNT strijdige cao-afspraken. ${ }^{10}$ In het wetgevingsproces werd op 8 november 2011 geconstateerd dat het kabinet en de Tweede Kamer dicht bij elkaar stonden in de wens de normering van topinkomens in de publieke en semipublieke sector bij wet te regelen. ${ }^{11}$ Deze constatering kreeg een maand later een passend vervolg. Wetsontwerp 32600 werd, na via amendementen nog te zijn 'aangescherpt', op 6 december 2011 met algemene stemmen door de Tweede Kamer aangenomen. Deze amenderingen gaven in 2012 bij de behandeling van het wetsontwerp in de Eerste Kamer nogal wat stof tot nadenken. Het ging daarbij vooral over de generieke uitbreiding van het bereik van de WNT tot de tienduizenden instellingen van het type $\mathrm{ANBI}^{12}$ en tot de bonte verzameling van instellingen waarbij subsidies voor meer dan $50 \%$ de inkomsten uitmaken. Voorts boog de Eerste Kamer zich over het aangenomen amendement dat de zorgverleners generiek onder het bezoldigingsmaximum bracht ('verplaatsing van bijlage 3 naar bijlage $1^{\text {'13) }}$ ) en over het amendement dat de zorgverzekeraars bond aan een sectorale bezoldigingsnorm ('verplaatsing van bijlage 4 naar bijlage $3^{\prime 14}$ ). De minister gaf tijdens de behandeling van het wetsontwerp in de Eerste Kamer aan de ANBI's bij aanpassingswet met terugwerkende kracht weer uit de bijlage te schrappen. ${ }^{15}$ De minister gaf voorts aan in deze aanpassingswet met terugwerkende kracht een drempelbedrag op te nemen ten aanzien van de instellingen waarbij subsidies voor meer dan $50 \%$ de inkomsten uitmaken. Zonder deze ondergrens luidde het standpunt van de minister dat de WNT te dien aanzien de proportionaliteitstoets niet kon doorstaan en ook overigens ongewenste neveneffecten had. ${ }^{16}$ Uiteindelijk nam ook de Eerste Kamer op 13 november 2012 het wetsontwerp met algemene stemmen aan. ${ }^{17}$ Dat

10 Kamerstukken II 2010/11, 32 600, nr. 3, p. 1. Die eenmaligheid vormt natuurlijk een te passeren station (zie de korte beschouwing over het regeerakkoord van 29 oktober 2012 in de tekst in par. 4).

11 Kamerstukken II 2011/12, 32 600, nr. 27, p. 1.

12 ANBI staat voor algemeen nut beogende instelling. Denk aan instellingen op het terrein van de 'goede doelen'. Het voordeel van schenken aan een ANBI is dat de schenking bij de Nederlandse fiscus aftrekbaar is van het belastbaar inkomen.

13 Dat wil zeggen: van het tweede regime naar het eerste regime. Zie over de drie regimes in de tekst par. 2.4 .

14 Dat wil zeggen: van het derde regime naar het tweede regime.

15 Zie Kamerstukken I 2011/12, 32 600, nr. F, p. 4. De verwachting is dat de aanpassingswet begin 2013 bij de Tweede Kamer wordt ingediend. Het ligt in de bedoeling dat de aanpassing(en) nog in 2013 in werking treedt (treden).

16 Zie Kamerstukken I 2011/12, 32 600, nr. F, p. 5 en 7. Op 6 november 2012 gaf de minister aan bij het drempelbedrag te denken aan vijf ton aan subsidies per jaar als ondergrens. Zie Handelingen I 6 november 2012, p. 6-7-31. Bovendien ligt het in de bedoeling dat de WNT ten aanzien van deze instellingen bepaalt dat de subsidie gedurende een nog precies te bepalen aantal jaren (gedacht wordt aan drie aaneengesloten jaren) wordt verstrekt, zodat wordt voorkomen dat een gesubsidieerde instelling het ene jaar wel en het andere jaar niet aan de eisen van de WNT moet voldoen.

17 Gedurende het wetgevingstraject betreffende de reparatiewet zal de WNT niet worden gehandhaafd ten opzichte van ANBI's die niet overigens al onder de WNT vallen en evenmin ten aanzien van kleine subsidieontvangers. Zie Kamerstukken I 2011/12, 32 600, nr. H, p. 14-15. 
geschiedde niet alleen met de toezegging dat het kabinet in 2013 met een aanpassingswetsvoorstel komt, maar ook in de wetenschap dat het regeerakkoord van eind oktober 2012 aanstuurt op een verdere aanscherping.

\section{De contouren van de WNT}

\subsection{De publieke en semipublieke sector}

De WNT heeft betrekking op de gehele publieke sector. Het gaat om alle lichamen die krachtens publiek recht zijn ingesteld (art. 1.2). De werkingssfeer van de WNT omvat daarnaast de privaatrechtelijk vormgegeven zelfstandige bestuursorganen (art. 1.3 lid 1 onderdeel a) en de overige aan de publieke sector verbonden privaatrechtelijke rechtspersonen (art. 1.3 lid 1 onderdeel b). De WNT richt zich tot slot tot de semipublieke sector (art. 1.3 lid 1 onderdeel c, art. 1.4 lid 1 en art. 1.5 lid 1).

Rechtspersonen en instellingen die niet onder de reikwijdte van de wet zijn gebracht, kunnen zo nodig alsnog bij algemene maatregel van bestuur (AMvB) binnenboord worden gehaald (art. 1.3 lid 2, art. 1.4 lid 2 en art. 1.5 lid 2). Verwijdering is eveneens mogelijk (art. 1.3 lid 3, art. 1.4 lid 3 en art. 1.5 lid 3).

De aanduiding 'semipubliek' viel niet scherp te definiëren. De commissie-Dijkstal achtte in het vijfde advies van september 2007 de term te veelomvattend en te fluïde. ${ }^{18}$ Het wetsontwerp koos daarom voor een andere afbakening: het expliciet en volledig uitschrijven van de doelgroep, inclusief het gewenste bijpassende normeringsinstrumentarium. De wetgever hanteerde ten behoeve van het bepalen van de positie van een instelling (wel of niet 'semipubliek') de vier criteria die de commissie-Dijkstal aanreikte: (1) de status van rechtspersoon met een wettelijke taak, ${ }^{19}$ (2) de mate waarin men publieke middelen ontvangt, ${ }^{20}$ (3) het publieke belang dat de organisatie behartigt, ${ }^{21}$ en (4) de mate waarin sprake is van commerciële concurrentie. ${ }^{22}$ De semipublieke sector betreft aldus de rechtspersonen of instellingen die na weging van de genoemde criteria zijn ingedeeld in de ver-

18 Advies 'Normeren en waarderen', bijlage bij Kamerstukken II 2006/07, 28 479, nr. 32.

19 Dit zijn instellingen van wie de taken of een deel daarvan bij wet zijn geregeld en die uit een heffing worden bekostigd. Zie Kamerstukken II 2010/11, 32 600, nr. 3, p. 10.

20 Indien een instelling eenmaal tot de semipublieke sector is gerekend, is een bezoldiging die wordt bekostigd uit private middelen geen grond toe te staan dat die bezoldiging de krachtens de WNT geldende normen overschrijdt. Zie Kamerstukken II 2010/11, 32 600, nr. 3, p. 10.

21 Kamerstukken II 2010/11, 32 600, nr. 3, p. 10. Onder 'publiek belang' verstaat de regering in navolging van de Wetenschappelijke Raad voor het Regeringsbeleid een maatschappelijk belang waarvan de overheid zich de behartiging heeft aangetrokken (bijvoorbeeld de zorg). Zie Kamerstukken II 2010/11, 32 600, nr. 8, p. 9. Ten aanzien van de woningcorporaties werd de keuze voor het zwaarste regime bepaald door de publieke taak. Hun vermogen heeft een expliciete maatschappelijke bestemming. Zie Kamerstukken II 2011/12, 32 600, nr. 27, p. 5. Voorts speelde een belangrijke rol dat een niet onaanzienlijk deel van de woningcorporaties hoger beloonde dan op basis van de eigen code is toegestaan. Zie Handelingen II 12 oktober 2011, p. 11-2-9. Voor de zorgsector geldt het regime van de sectorale bezoldigingsnorm, waarbij een rol speelde dat de zorg zich binnen de semipublieke sector op de grootste afstand tot de publieke sector bevindt. Zie Kamerstukken II 2011/12, 32 600, nr. 27, p. 9. 
schillende bezoldigingsregimes. ${ }^{23}$ Tijdens het wetgevingsproces is uitvoerig gediscussieerd over de positie van bepaalde sectoren (zie bijvoorbeeld de hiervoor genoemde amendementen betreffende de zorgsector, de ANBI's en de voor meer dan $50 \%$ gesubsidieerde instellingen) en individuele instellingen. De systematiek is evenwel hetzelfde gebleven: de omvang van de semipublieke sector wordt door (de bijlagen bij) de WNT gedefinieerd. ${ }^{24}$

Staatsdeelnemingen vallen buiten het bereik van de WNT. De staat heeft als aandeelhouder reeds op grond van de privaatrechtelijke relatie het recht het bezoldigingsbeleid bij de deelneming vast te stellen. ${ }^{25}$ De casus van de bezoldiging van de na de nationalisering door de staat begin 2013 aangetrokken topfunctionarissen van SNS Bank is voor een enkeling ongetwijfeld boeiend, maar valt buiten de kaders van de WNT.

\subsection{De topfunctionaris en zijn dienstverband}

\section{- De topfunctionaris}

Artikel 1.1 onderdeel b somt zo concreet mogelijk op om welke functies het gaat. Het betreft de hoogste leidinggevenden binnen organisaties waarop de wet van toepassing is. Zit men bij het Rijk in een topmanagementgroep, dan is sprake van een topfunctie. Bij de semipublieke sector dient men te denken aan de leden van de hoogste uitvoerende en toezichthoudende organen, alsmede de hoogste ondergeschikte of de leden van de groep hoogste ondergeschikten van dat orgaan en degene of degenen belast met de dagelijkse leiding. De gehanteerde titulatuur doet er niet toe. De WNT biedt geen ruimte voor omzeiling via gebruik van een sobere functieaanduiding. Andersom betekent het feit dat iemand deel uitmaakt van het topkader niet dat hij een topfunctionaris is (top is dus niet zomaar top als er top op staat). De WNT nodigt derhalve niet uit tot enige wildgroei op het door sommigen zo belangrijk bevonden terrein van de functiebenaming.

Er is alleen sprake van een topfunctionaris indien de betrokkene leidinggeeft aan de gehele organisatie. ${ }^{26}$ Een vestigingsdirecteur (of bijvoorbeeld een decaan van een faculteit) is derhalve in die rol geen topfunctionaris. ${ }^{27}$ Door stapeling met

23 Kamerstukken II 2010/11, 32 600, nr. 3, p. 15.

24 Kamerstukken I 2011/12, 32 600, nr. F, p. 2.

25 Kamerstukken II 2010/11, 32 600, nr. 3, p. 21. De minister van Financiën hanteert een beoordelingskader. Zie Kamerstukken II 2008/09, 28 479, nr. 39. Het verslag van oktober 2010 van de resultaten van dit beleid is te vinden in Kamerstukken II 2009/10, 28 165, nr. 115. Zie over staatsdeelnemingen voorts Kamerstukken II 2010/11, 32 600, nr. 8, p. 22-24.

26 Kamerstukken I 2011/12, 32 600, nr. F, p. 15.

27 Vgl. Ktr. Utrecht 30 augustus 2012, JAR 2012/254 m.nt. Janssen (Mitros). De kwestie betrof de ontbinding van de arbeidsovereenkomst met een directeur van een werkmaatschappij van een woningbouwcorporatie. De werkgever stelde dat hoge vergoedingen in deze sector niet horen en verwees naar het wetsvoorstel WNT. De rechter overwoog dat de niet statutaire directeur van een werkmaatschappij niet onder het begrip topfunctionaris valt. Er volgde toewijzing van een ontslagvergoeding conform de kantonrechtersformule op basis van C=1 (194 mille). Het oordeel van de kantonrechter dat een directeur werkmaatschappij niet onder de WNT valt nu deze functionaris niet (mede) leidinggeeft aan de hele organisatie, lijkt mij in het licht van de wetsgeschiedenis geheel juist. 
andere rollen kan de zaak anders komen te liggen. Indien de vestigingsdirecteur tevens met anderen zitting heeft in het managementteam of in het bestuur waarin de besluiten vallen voor de gehele organisatie, dan maakt dit hem tot topfunctionaris. Ik zie het zo dat men pas topfunctionaris is indien men medeverantwoordelijk is voor het nemen van de besluiten voor de gehele organisatie. De directeur $\mathrm{P} \& \mathrm{O}$ is geen topfunctionaris als hij slechts rapporteert aan de voorzitter van de directie en niet zelf lid van de directie of het managementteam is. Is hij wel lid van het managementteam of de directie, dan is hij topfunctionaris en maakt het daarbij niet uit dat hij aan de directievoorzitter rapporteert. ${ }^{28}$ Indien de werkelijkheid afwijkt van de schijn, is de werkelijkheid beslissend.

Veel organisaties kennen een vorm van overleg tussen het bestuur en afdelingshoofden, vestigingshoofden of vergelijkbare sleutelfiguren. Dergelijk overleg is primair bedoeld voor communicatie en het verkrijgen van draagvlak, ter voorbereiding van besluitvorming ten aanzien van de hele organisatie. Dit overleg draagt bij aan de kwaliteit van die besluitvorming, maar zulk overleg vormt geen bestuursorgaan en maakt de betrokken 'sparringpartners' van het bestuur in mijn visie niet tot topfunctionaris. Zij dragen immers geen verantwoordelijkheid voor de genomen besluiten.

Draagt men wel verantwoordelijkheid voor de besluiten ten aanzien van de hele organisatie, bijvoorbeeld als bestuurder of lid van het managementteam, maar bestaat het overgrote deel van de dagelijkse werkzaamheden uit werk ten behoeve van een onderdeel van die organisatie, dan is en blijft men topfunctionaris voor het geheel. Deze conclusie heeft iets van een evidentie, nu anders door een ver doorgevoerde compartimentering van aandachtsgebieden de WNT alsnog eenvoudig buitenspel wordt gezet. Mijn zienswijze strookt voorts met de manier waarop men in organisaties naar de leiding kijkt. Een vestigingsdirecteur die tevens als lid van de statutaire directie de hele organisatie aanstuurt, heeft intern een andere en hogere positie dan de vestigingsdirecteur die slechts in die vestigingsrol opereert en aan het bestuur rapporteert. Die hogere positie is er niet ten dele. Men is topfunctionaris of niet en niet voor een beetje.

De WNT heeft met uitzondering van de openbaarmakingsverplichting in het derde regime (zie omtrent de drie regimes paragraaf 2.4) geen betrekking op de arbeidsvoorwaarden van andere werknemers dan topfunctionarissen. ${ }^{29}$ De wetgever ging er, ter zijde, van uit dat de topfunctionarissen slechts bij uitzondering aan lager geplaatsten een bezoldiging zullen toekennen die hun eigen bezoldiging te boven gaat. ${ }^{30}$

\section{- Het dienstverband}

Het dienstverband is een gedefinieerd (verzamel)begrip. Artikel 1.1 onderdeel d refereert aan de aanstelling, de arbeidsovereenkomst of andere titel op grond waarvan de topfunctionaris tegen betaling zijn opgedragen taken vervult. De MvT 
geeft als voorbeeld van een andere titel de inlening van een topfunctionaris via een management-bv. Het gaat nadrukkelijk om een voorbeeld. In feite maakt het niet uit hoe 'partijen' de relatie vormgeven. De WNT duidt daarbij in artikel 1.1 onderdeel c een uitlenende derde (de natuurlijke of rechtspersoon die de topfunctionaris ter beschikking stelt: een management-bv, een adviesbureau of een uitzendbureau) tevens als 'partij' in de zin van de WNT. De WNT barricadeert pogingen om via tussenplaatsing van een derde de WNT te omzeilen. De WNT sluit aan bij de taakvervulling tegen betaling en bekommert zich welbeschouwd, althans na verloop van een bepaalde interim-periode (zie hierna), niet om de aard van de contractuele omgeving. ${ }^{31}$

De WNT bevat voor de interimmer een aparte regeling. In geval de functie van topfunctionaris in een periode van achttien maanden voor meer dan zes maanden wordt vervuld anders dan op grond van een aanstelling of een arbeidsovereenkomst, bedraagt de voor de vervulling per kalenderjaar verschuldigde vergoeding niet meer dan de maximale bezoldiging (in het eerste regime, zie art. 2.1 lid 4), respectievelijk de maximale bezoldigingsnorm (in het tweede regime, zie art. 3.1 lid 5). De periode van zes maanden behoeft niet aaneengesloten te zijn. Het gaat erom dat men binnen een periode van achttien maanden zes maanden als topfunctionaris heeft gewerkt. Dit voorkomt, aldus de MvT (nog uitgaande van '12 uit $18^{\prime 32}$ ), draaideurconstructies. Bij een kortere periode dan zes maanden mag worden gesproken van interim-functievervulling, waarbij ruimte moet bestaan voor vergoeding aan de organisatie waar de ingeleende functionaris in dienst is. Men mag dan dus meer betalen dan het maximum. Bij langduriger inlening mag de instelling ten behoeve van de interim-manager aan de rechtspersoon die hem uitleent $a b$ initio niet meer betalen dan het geldende maximum. ${ }^{33}$ De keuze voor de genoemde 'wachttijd' houdt verband met de gedachte dat bij kortere periodes vaak sprake is van noodsituaties waarbij de instelling afhankelijk is van de markt. Zodra echter iemand langer dan zes maanden werkzaam is, wordt met terugwerkende kracht vanaf het begin (!) het bezoldigingsmaximum van toepassing. ${ }^{34}$ Wie als interimmer bij een noodsituatie instapt en een honorering bedingt dat uitstijgt boven de maximale bezoldiging onder de WNT, zorgt er aldus hoogstwaarschijnlijk voor dat hij binnen die zes maanden weer wegkomt.

31 Kamerstukken II 2010/11, 32 600, nr. 3, p. 37. We zien het punt terug bij de openbaarmakingsverplichting. Zie Kamerstukken II 2010/11, 32 600, nr. 3, p. 48.

32 De Tweede Kamer vond de oorspronkelijke periode van twaalf maanden (binnen een tijdsbestek van achtien maanden) te lang en aanvaardde een amendement (Kamerstukken II 2011/12, 32 600 , nr. 35) dat deze periode terugbracht tot zes maanden, nadat minister Donner tijdens het debat in de Tweede Kamer had aangegeven een periode van zes maanden een werkbaar compromis te vinden, mits er de mogelijkheid zou zijn van een gecontroleerde uitzondering als een en ander door bijzondere omstandigheden langer zou duren. Zie Handelingen II 1 december 2011, p. 31-10-98.

33 Overigens is vanaf de start van de relatie het bepaalde in art. 2.1 onverkort van toepassing op de externe inhuur van topfunctionarissen bij de rijksoverheid. Daarnaast zal deze inhuur moeten voldoen aan de regels van het inkoopbeleid rijksoverheid. Kamerstukken II 2010/11, 32 600, nr. 3, p. 43/44.

34 Kamerstukken II 2010/11, 32 600, nr. 8, p. 12. Zie tevens Kamerstukken II 2011/12, 32 600, nr. 27, p. 12/13. 
Een inleningsconstructie doet geen afbreuk aan de betrokkenheid en verantwoordelijkheid van de door de verantwoordelijke vertegenwoordigde rechtspersoon en de topfunctionaris zelf. Wel levert een inleningsconstructie in voorkomend geval een extra debiteur op. Het boven het maximum betaalde kan als onverschuldigd betaald worden opgeëist van zowel de topfunctionaris als de natuurlijke of rechtspersoon die de topfunctionaris ter beschikking stelde (art. 5.5 lid 2).

\subsection{De begrippen bezoldiging en beloning in de eerste twee regimes}

\section{- De bezoldiging}

De definitie van bezoldiging in artikel 1.1 onderdeel e zoekt aansluiting bij artikel 2:383c lid 1 van het Burgerlijk Wetboek (BW) en in het verlengde daarvan bij de Richtlijnen van de Raad voor de Jaarverslaggeving. Deze keuze houdt verband met het feit dat in de visie van de wetgever de begrippen uit dit laatste artikellid ruime bekendheid genieten. Wij kunnen dus putten uit de ervaring die met de omschrijving in artikel 2:383c lid $1 \mathrm{BW}$ is opgedaan. Ook voor deze regel geldt echter dat er geen regel is zonder uitzondering: het in de WNT gehanteerde bezoldigingsbegrip omvat niet de uitkering wegens beëindiging van het dienstverband. Het wel opnemen van deze uitkering zou tot gevolg hebben dat er bij een bezoldiging net onder het maximum geen ruimte meer zou bestaan voor een ontslagvergoeding. Dit effect werd niet beoogd. Om die reden normeert en definieert de WNT de uitkering wegens beëindiging van het dienstverband apart in artikel 2.10 en artikel 3.7 (het thema van de ontslagvergoeding komt apart ter sprake in paragraaf 2.5)..$^{35}$

De MvT toont besef van de mogelijkheid, teneinde een overschrijding van de toepasselijke norm te ontlopen, dat posten worden geboekt ten laste van een ander kalenderjaar dan waarop ze betrekking hebben. Om de praktijk handvatten te bieden voor de uitvoering en om ontwijkgedrag tegen te gaan kan de minister van Binnenlandse Zaken en Koninkrijksrelaties krachtens artikel 1.9 nadere regels stellen over de uitleg van het begrip bezoldiging of over de wijze waarop een onderdeel van de bezoldiging wordt toegerekend aan een kalenderjaar. ${ }^{36}$ Zo zou een van het gebruik afwijkende praktijk van het boeken van de vakantietoeslag met zo'n ministeriële regeling kunnen worden bestreden. ${ }^{37}$

De normering geldt naar rato voor deeltijdfuncties, een dienstverband voor minder dan een kalenderjaar of voor functievervulling anders dan op grond van een arbeidsovereenkomst of aanstelling (art. 2.1 lid 2 en 3). Het bezoldigingsmaximum wordt niet verhoogd bij een dienstverband met een langere arbeidsduur dan een voltijds dienstverband. ${ }^{38}$ In het debat in de Eerste Kamer kwam het wat curieuze voorbeeld ter sprake van een topfunctionaris die fulltime binnen de WNTnorm aan de slag was bij een (semi)publieke instelling en daarnaast nog drie ton 
bijverdiende in de private sector. De minister achtte dit in strijd met de geest van de WNT, maar beantwoordde de vraag of er iets aan viel te doen ontkennend. In zijn onderbouwing van deze visie gaf de minister nog een tweede voorbeeld: de fulltime topfunctionaris die keurig binnen de WNT-norm wordt betaald en daarnaast in zijn vrije tijd boeken van het type bestseller schrijft en daarmee miljonair wordt. Deze casus kon, terecht, door de beugel. ${ }^{39}$

\section{- De beloning}

De post beloning is gedefinieerd als de som van de periodiek betaalde beloningen en de winstdelingen en bonusbetalingen, met uitzondering van de socialeverzekeringspremies en met uitzondering van belastbare vaste en variabele onkostenvergoedingen (art. 1.1 onderdeel f). Deze definitie volgt hetgeen de Raad voor de Jaarverslaggeving onder 'periodiek betaalde beloningen' en onder 'winstdelingen en bonusbetalingen' verstaat. ${ }^{40}$ Wel dient men in de gaten te houden dat beloningen die betaalbaar zijn op termijn en betrekking hebben op de beëindiging van het dienstverband geen deel uitmaken van de beloning, maar behoren tot het in paragraaf 2.5 te bespreken debiet van de uitkering wegens beëindiging van het dienstverband.

Indien van toepassing, wordt de auto van de zaak meegeteld als beloningscomponent. Een ter beschikking gestelde auto wordt beschouwd als beloning in natura, die men waardeert overeenkomstig de fiscale bijtelling. ${ }^{41} \mathrm{Bij}$ amendement is in de WNT vastgelegd dat partijen geen winstdelingen, bonusbetalingen of andere vormen van variabele beloning overeenkomen, tenzij die overeenkomst betrekking heeft op bij of krachtens AMvB bepaalde uitzonderingen (art. 2.11 in het eerste regime en art. 3.8 in het tweede regime). In de toelichting werd verwoord dat bestuurders die werken voor de publieke zaak, niet financieel geprikkeld behoeven te worden om hun best te doen voor een zo goed mogelijke (semi)publieke dienstverlening. Bij eventuele bij $\mathrm{AMvB}$ te regelen uitzonderingen werd gedacht aan gratificaties die niet direct waren gerelateerd aan de functionele prestaties, zoals in het geval van een ambtsjubileum, een mobiliteitstoeslag of een bindingspremie. ${ }^{42}$ Ik ben geneigd de aanduiding 'andere vormen van variabele beloning' ruim te nemen. Wij lezen dat de voormalig directeur huisvesting van Amarantis opdrachtnemers van Amarantis inzette bij het opknappen van zijn woning. Dat is niet alleen ongepast gedrag, maar meestal ook een indirecte ('andere') vorm van een buiten de boeken blijvende variabele beloning. ${ }^{43}$

39 Handelingen I 6 november 2012, p. 6-7-34.

40 Kamerstukken II 2010/11, 32 600, nr. 3, p. 24.

41 Kamerstukken I 2011/12, 32 600, nr. H, p. 8.

42 Kamerstukken II 2011/12, 32 600, nr. 40, p. 2. Men proeft welhaast in de tekst iets van een 'suggestie' over de noodzaak van financiële prikkels in de zakelijke dienstverlening.

43 Vgl. de brief van de minister van OCW van 14 februari 2013 met als bijlage het rapport van de Commissie onderzoek financiële problematiek Amarantis van dezelfde datum. Kamerstukken II 2012/13, 33 495, nr. 6. Het ging in casu kennelijk slechts om ongepast gedrag, er was slechts sprake van een schijn van belangenverstrengeling. Dat kan, maar het komt natuurlijk wel voor dat er in dit soort situaties ruimte zit in het in rekening gebrachte bedrag in vergelijking met wat een dergelijke leverancier normaal aan een klant rekent. Vandaar ook de verwijzing naar een ongepast karakter. 


\subsection{Drie bezoldigingsregimes}

Om recht te doen aan de verschillen binnen de semipublieke sector en de verschillende positie ten opzichte van de arbeidsmarkt waarin de onderdelen van de semipublieke sector bewegen en de verschillen met en in de publieke sector, voorziet de WNT in drie bezoldigingsregimes. In aflopende zwaarte gaat het om (1) een bezoldigingsmaximum voor de publieke sector en dat deel van de semipublieke sector dat op zeer korte afstand van de publieke sector staat (vermeld in art. 1.2, art. 1.3 en genoemd in de bijlagen 1 en 2), (2) een sectorale bezoldigingsnorm die hoger mag zijn dan het bezoldigingsmaximum voor het deel van de semipublieke sector dat 'wat verder van de publieke sector af staat' (vermeld in art. 1.4 en genoemd in bijlage 3), en (3) een openbaarmakingsverplichting voor de publieke sector, de delen van de semipublieke sector waarvoor het maximum of een sectornorm geldt en voor die instellingen waarvoor het kabinet normering van de bezoldiging te zwaar acht (genoemd in bijlage 4), maar waarvan openbaarmaking van de bezoldiging in het kader van de WNT gewenst is. ${ }^{44}$

De eerste twee regimes zijn alleen van toepassing op topfunctionarissen die een dienstverband hebben met de betrokken instellingen. Het derde regime geldt voor (1) alle werknemers in dienst van de instelling van wie de bezoldiging uitstijgt boven het bezoldigingsmaximum (zonder naam en toenaam: slechts de functiebenaming en de bezoldiging wordt vermeld ${ }^{45}$ ) en (2) de topfunctionarissen en gewezen topfunctionarissen die nog bij de instelling in dienst zijn (met naam en toenaam). ${ }^{46}$ Ten aanzien van deze laatste groep geldt dus: eens een topfunctionaris, altijd een topfunctionaris. Wie bijvoorbeeld in het kader van een reorganisatie in 2013 zijn topfunctie verloor en in een lagere functie (net onder de top) nog vele jaren zijn dienstverband met de instelling voortzet, blijft tot in de lengte van die jaren met naam en toenaam vallen onder de openbaarmakingsverplichting, ook indien de bezoldiging overigens sinds de demotie niet uitstijgt boven het bezoldigingsmaximum. ${ }^{47}$

De regels over het bezoldigingsmaximum en de sectorale bezoldigingsnorm in het eerste en tweede regime betreffen verplichtingen van de betrokken rechtspersonen en instellingen en de topfunctionarissen. Dit geldt niet voor de openbaarmakingsverplichting in het derde regime. De wettelijke bepalingen omtrent deze verplichting richten zich uitsluitend tot de verantwoordelijken (art. 1.1 onderdeel a) binnen de rechtspersonen en instellingen. ${ }^{48}$

45 Kamerstukken II 2010/11, 32 600, nr. 3, p. 29. Deze wijze van openbaarmaking komt overeen met de openbaarmaking in de Wopt, waarover het College bescherming persoonsgegevens een positief advies uitbracht. Vgl. Kamerstukken II 2004/05, 30 189, nr. 3, p. 14.

46 Kamerstukken II 2010/11, 32 600, nr. 3, p. 11 en p. 48.

47 Ik geef het adviescollege normeringsbeleid in overweging bij de evaluatie van de WNT na te denken over een voorstel om te komen tot een passender uitlooptijd. Denk aan een openbaarmakingsplicht die na het einde van de 'topperiode' nog maximaal vier volle kalenderjaren voortduurt. 
- Het eerste regime: het bezoldigingsmaximum (art. 2)

De commissie-Dijkstal adviseerde dat het salaris van de minister de top in de publieke sector definieert. Het kabinet nam dit advies in 2004 over. Het salarisniveau van een minister was echter ernstig achtergebleven bij wat de commissieDijkstal als het juiste niveau zag. Het advies luidde een grote inhaalslag van circa $50 \%$ te maken. De commissie-Dijkstal adviseerde de achterstand in twee stappen in te lopen: $30 \%$ ineens en $20 \%$ in een volgende kabinetsperiode. ${ }^{49}$ In verband met de economische situatie maakte het kabinet een pas op de plaats. In 2009 werd besloten zelfs de voorgestelde eerste stap van een verhoging ineens van $30 \%$ niet, en evenmin ten dele, te zetten. Deze pas op de plaats leidde ertoe dat de WNT het wettelijke normbedrag niet relateert aan het salaris van een minister, maar uitgaat van een bedrag in euro's. ${ }^{50}$ Het bezoldigingsmaximum bedraagt overeenkomstig artikel 2.3 lid 1 per kalenderjaar ten hoogste een beloning van $€ 187.340,{ }^{51}$ verhoogd met het werkgeversdeel van de verplichte sociale premies, een gemaximeerd bedrag aan vergoeding van onkosten van $€ 7559$ en de op een bedrag van $€ 28.767$ gemaximeerde werkgeversbijdrage aan beloningen betaalbaar op termijn (het werkgeversdeel van de pensioenpremie als bedoeld in art. 1.1 onderdeel $\left.\mathrm{h}^{52}\right) .{ }^{53}$ Het bezoldigingsmaximum bestaat aldus uit vier posten: beloning, werkgeversdeel sociale premies, belastbare onkostenvergoeding en de beloningen betaalbaar op termijn. Er is pas sprake van een overschrijding van het bezoldigingsmaximum indien de bezoldiging in voorkomend geval meer bedraagt dan de som van de vier genoemde posten samen. Voor de beoordeling van de overschrijding telt het saldo. Dit voorkomt dat door een schuiven met posten toch een hogere bezoldiging kan worden verantwoord. Het is in het systeem van de WNT aan werkgevers en werknemers uit te maken welk deel van de bezoldiging wordt besteed aan welke post. ${ }^{54}$

Artikel 2.4 biedt de basis voor een individuele afwijking van het wettelijk maximum van de bezoldiging voor exceptionele gevallen, die blijkens de MvT 'thans niet kunnen worden voorzien'. Een uitzondering op grond van artikel 2.3 wordt openbaar gemaakt in de Staatscourant. In de nota naar aanleiding van het verslag

49 Kamerstukken II 2010/11, 32 600, nr. 3, p. 3.

50 Kamerstukken II 2010/11, 32 600, nr. 3, p. 4-5 en 11. Het beloningsmaximum van $€ 187.340$,(naar de stand van de peildatum 1 januari 2010) komt overeen met $130 \%$ van de beloning van een minister. Zie ook Kamerstukken II 2010/11, 32 600, nr. 8, p. 4 en het debat in de Tweede Kamer, Handelingen II 12 oktober 2011, p. 11-2-5.

51 Dit bedrag wordt jaarlijks bij ministeriële regeling van de minister van Binnenlandse Zaken aangepast aan de wijziging van de beloning van de rijksambtenaren in dat jaar. Zie Kamerstukken II 2010/11, 32 600, nr. 3, p. 11/12. Het bedrag met peildatum 1 januari 2010 is tijdens het wetgevingsproces niet aangepast.

52 De post beloningen betaalbaar op termijn is genormeerd op een niveau dat in directe relatie staat tot de hoogte van de beloning. Het totaal van de werkgeversbijdragen kwam bij het Rijk op basis van de op 1 januari 2010 geldende percentages uit op $€ 28.767$. Dit bedrag zal jaarlijks bij ministeriële regeling worden aangepast aan de dan geldende percentages. Zie Kamerstukken II 2010/11, 32 600, nr. 3, p. 12. Het bedrag is tot nu toe niet aangepast.

53 Een eventuele indexering van de maximale bezoldigingsbedragen vindt jaarlijks plaats in de maand november van het jaar voorafgaand aan het jaar waarin de norm geldt. Vgl. Kamerstukken II 2010/11, 32 600, nr. 3, p. 14.

54 Kamerstukken II 2010/11, 32 600, nr. 8, p. 26. 
gaf de minister het voorbeeld dat iemand buiten de publieke en semipublieke sector meer kan verdienen, maar over een specifieke deskundigheid beschikt die voor de desbetreffende topfunctie nodig is. ${ }^{55}$ Artikel 2.5 biedt de mogelijkheid dat een betrokken minister bij ministeriële regeling, in overeenstemming met de ministerraad, een hoger maximum vaststelt voor topfuncties bij een specifiek privaatrechtelijk zelfstandig bestuursorgaan (denk bijvoorbeeld aan De Nederlandsche Bank en de Autoriteit Financiële Markten).

Op grond van een desbetreffend amendement is de bezoldiging van de leden van een raad van toezicht of raad van commissarissen gemaximeerd op 5\% (en 7,5\% voor de voorzitter) van de voor de instelling geldende maximale bezoldiging (art. 2.2). Dit geldt behoudens een bij $A M v B$ vast te stellen uitzondering vanwege de complexiteit en tijdsbesteding van de werkzaamheden van de toezichthouders. ${ }^{56}$ De betrokken minister is voorts, zoals het aangenomen amendement verwoordde, bevoegd bij ministeriële regeling forfaitair een getal vast te stellen dat geldt als de omvang van het dienstverband van de leden van de toezichthoudende organen van rechtspersonen en instellingen (art. 2.8). Dit voorkomt eventuele problemen bij de vaststelling van de bezoldiging in het geval dat geen sprake is van een afgesproken tijdsbesteding. ${ }^{57}$ Bij toezichthouders is die tijdsbesteding inderdaad anders al gauw een onbekende grootheid.

De voor de verschillende onderdelen van de publieke en semipublieke sector verantwoordelijke ministers kunnen bij ministeriële regeling voor de categorieën waarop het bezoldigingsmaximum geldt een lager maximum vaststellen, een zogeheten 'verlaagd plafond' (art. 2.6). Voor een verlaagd plafond kan aanleiding zijn als binnen een deelsector de bezoldiging van de topfunctionarissen te snel naar het maximum dreigt te groeien. De minister kan instellingen voorts per deelsector verdelen in klassen met een lagere norm (art. 2.7 en art. 3.4). Dit geschiedt op grond van objectieve criteria. Artikel 2.7 lid 1 noemt als voorbeeld het criterium dat betrekking heeft op de omvang van de instelling (het aantal leerlingen van een school op een bepaalde peildatum ${ }^{58}$ ). De betrokken minister is dan bevoegd jaarlijks per klasse een (verlaagd) plafond vast te stellen. ${ }^{59}$ Op deze manieren voorziet de WNT met vooruitziende blik in het gekende fenomeen van 
het risico dat een bovengrens een aantrekkingskracht uitoefent op wat zich nog op een lager niveau bevindt, een opdrijvend effect heeft. ${ }^{60}$

- Het tweede regime: de (sectorale) bezoldigingsnorm (art. 3)

De sectoraal te bepalen bezoldigingsnorm valt waarschijnlijk door het door de betrokken minister gekozen (hogere) bedrag minder zwaar op een enkele maag dan het bezoldigingsmaximum in het eerste regime. Dit vloeit mede voort uit de gedachte dat het in beginsel gaat om regels die in de sector onderling zijn afgesproken. De vast te stellen norm betreft derhalve vooral een handhavingsnorm. ${ }^{61}$ Het bedrag dat de betrokken minister na consultatie van de brancheorganisaties en/of individuele instellingen jaalijks als norm vaststelt, is evenwel 'nagelvast'. Bij het bepalen van de norm houdt de minister rekening met de relevante lonen in de publieke sector en de markt, de lonen voor andere functies in de sector (zodat er geen grote afstand met de cao-lonen ontstaat) en het draagvlak voor dergelijke bezoldigingen (art. 3.6 lid 2), maar op de gekozen norm worden vervolgens geen uitzonderingen toegestaan. ${ }^{62}$

Op grond van een amendement is de bezoldiging van de leden van een raad van toezicht of raad van commissarissen ook in het tweede regime gemaximeerd op $5 \%$ (en 7,5\% voor de voorzitter) van de voor de instelling geldende maximale bezoldiging (art. 3.2). Dit geldt behoudens een bij AMvB vast te stellen uitzondering vanwege de complexiteit en tijdsbesteding van de werkzaamheden van de toezichthouders. ${ }^{63}$ Het lijkt me juist dat het maximale percentage niet een afgeleide is van de bezoldiging van de topfunctionarissen op wie men toezicht houdt. Dat laat onverlet dat indien deze $\mathrm{AMvB}$ er in het tweede regime niet komt, het mede gezien de reputationele afbreukrisico's waarschijnlijk is dat men kandidaten voor toezichthoudende posities bij de grote en complexe (en publiciteitsgevoeli-

60 Zo werd in het afgelopen decennium het maximum van de ontslagvergoeding op grond van de Code Corporate Governance van eenmaal het jaarsalaris meestal tevens de ondergrens. Op 17 december 2012 schreef minister Opstelten aan de Tweede Kamer niet zonder goede grond in het kader van wetsontwerp 32512 (omtrent de bevoegdheid tot aanpassing en terugvordering van bonussen en winstdelingen van bestuurders en dagelijks beleidsbepalers): 'In de Nederlandse praktijk is een vertrekvergoeding van één jaarsalaris de norm geworden.', zie Kamerstukken II 2012/13, 32 512, nr. 24, p. 3. Ik citeer voorts uit het debat in de Tweede Kamer omtrent wetsontwerp 32 600. Aan het woord is het Kamerlid Van Gent (GroenLinks): 'Als je gaat normeren, loop je namelijk enigszins het risico dat iedereen zich aan de maximale norm wenst te gaan houden. Dat werkt ook een beetje zo met de openbaarmaking van topinkomens: als je in die wereld niet op je max zit, ben je eigenlijk een loser', Handelingen II 11 oktober 2011, p. 10-19-73. Op p. 10-19-80 is Kamerlid Van der Staaij (SGP) aan het woord: 'Wie in de wet leest dat hij maximaal $€ 187.000$,- kan verdienen, kan bij een voorstel van $€ 100.000$,- zich heel gemakkelijk misdeeld voelen. Ik denk dat er reden is en blijft om ook kritisch te volgen of er niet een opwaartse druk ontstaat.' En op p. 10-19-82 in de woorden van Kamerlid Van der Burg (VVD): 'De VVD-fractie vindt het belangrijk dat voorkomen wordt dat salarissen altijd tegen het maximum worden vastgesteld dan wel te snel naar het maximum toe groeien.'

61 Vgl. Handelingen II 12 oktober 2011, p. 11-2-16.

62 Kamerstukken II 2010/11, 32 600, nr. 3, p. 13.

63 Kamerstukken II 2011/12, 32 600, nr. 33. 
gere) instellingen toch vooral moet zoeken in de bevlogen (en/of vermogende) sfeer van lieden voor wie geld geen rol speelt. ${ }^{64}$

- Het derde regime: de openbaarmakingsverplichting (art. 4)

De commissie-Dijkstal adviseerde dat een wettelijke basis een noodzaak is. Gelet op de in de WNT geregelde materie vloeit de eis van een wettelijke regeling voort uit artikel 10 van de Grondwet en artikel 8 van het Europees Verdrag tot bescherming van de rechten van de mens en de fundamentele vrijheden (EVRM). ${ }^{65}$ De MvT onderbouwt het standpunt dat de WNT de toets der kritiek van artikel 8 EVRM doorstaat met een verwijzing naar zaak C-465/00van het Hof van Justitie van de Europese Gemeenschappen (HvJ EG). ${ }^{66}$ De MvT achtte het met het oog op het nagestreefde doel noodzakelijk en proportioneel de openbaarmaking van de bezoldiging van de topfunctionarissen, anders dan die van de andere werknemers, op naam te laten plaatsvinden. Het argument van de persoonlijke levenssfeer werd in de weegschaal minder zwaar bevonden dan de op deze functionarissen rustende maatschappelijke verantwoordelijkheid om de op hen van toepassing zijnde normen na te leven. Bovendien treden zij naar buiten als vertegenwoordiger van hun instelling en is met openbaarmaking op functieniveau eenvoudig te achterhalen op welke persoon de openbaar gemaakte bezoldiging betrekking heeft. ${ }^{67}$ Van een persoonlijke levenssfeer op dit punt was, met andere woorden, al nauwelijks sprake. Ik treed in deze bijdrage niet in dit oordeel.

\subsection{De uitkering wegens beëindiging van het dienstverband: de ontslagvergoeding}

Artikel 1.1 onderdeel i definieert de uitkering wegens beëindiging van het dienstverband als de som van uitkeringen bij beëindiging van het dienstverband en beloningen betaalbaar op termijn die betrekking hebben op de beëindiging van het dienstverband, met uitzondering van uitkeringen die voortvloeien uit een algemeen verbindend verklaarde cao of een wettelijk voorschrift. Het tijdstip van betaling is niet relevant. Gekeken wordt naar de som van betalingen die in de loop der jaren zijn uitgekeerd, niet alleen de uitkering op of rondom het tijdstip van ontslag. De definitie volgt hetgeen de Raad voor de Jaarverslaggeving onder deze uitkeringen verstaat (afvloeiingsregeling, golden parachute, kantonrechtersformule, gouden handdruk). ${ }^{68}$

Partijen die vallen binnen het eerste of tweede regime komen geen uitkeringen overeen wegens beëindiging van het dienstverband, die gezamenlijk meer bedragen dan de som van de beloning en de voorzieningen ten behoeve van beloningen

In de hoop dat Marten Toonder mij niet euvel zou hebben geduid; de cap van $5 \%$ heeft iets weg van een Bommel-beding. Het aspect speelt niet in goede tijden, maar wel op momenten dat de instelling in zwaarder weer terechtkomt. Een toezichthoudende functie kan dan zeer tijdrovend zijn. Dit laat onverlet dat de honorering van een toezichthoudende functie, ook in de private sector, een zekere bescheidenheid behoort te hebben.

65 Zie daarover tevens Kamerstukken II 2010/11, 32 600, nr. 3, p. 28/29.

66 Kamerstukken II 2010/11, 32 600, nr. 3, p. 28. Het betreft HvJ EG 20 mei 2003, zaak C-465/00, Jur. 2003, p. 1-5014 (Osterreichischer Rundfunk).

67 Kamerstukken II 2010/11, 32 600, nr. 3, p. 29.

68 Kamerstukken II 2010/11, 32 600, nr. 3, p. 27. 
betaalbaar op termijn over de twaalf maanden voorafgaand aan de beëindiging van het dienstverband, tot ten hoogste $€ 75.000$ (art. 2.10 lid 1, art. 3.7 lid 1). De begrenzing tot $€ 75.000$ is absoluut (bij $\mathrm{AMvB}$ te wijzigen, indien de loonontwikkeling daartoe aanleiding geeft: art. 2.10 lid 2, art. 3.7 lid 2). Voor deeltijders wordt dit plafond naar rato herrekend. ${ }^{69}$ De begrenzing tot een 'jaar' is van toepassing bij een lagere vergoeding dan $€$ 75.000. In dit geval valt de bijl bij de som van de beloning over twaalf maanden en de werkgeversbijdrage in de beloning betaalbaar op termijn over twaalf maanden. ${ }^{70}$

Partijen komen niet overeen het dienstverband op een later tijdstip te beëindigen dan het tijdstip waarop de topfunctionaris de uitoefening van zijn taken beëindigt (art. 2.10 lid 3, art. 3.7 lid 3). Een beding dat hiermee in strijd is, is nietig. Bezoldigingen die zijn betaald over een periode dat de topfunctionaris zijn opgedragen taken niet meer vervult, zijn onverschuldigd betaald (art. 1.6 lid 3). Dit moet voorkomen dat partijen een ontslag laten ingaan op een later tijdstip dan dat de topfunctionaris zijn taken heeft beëindigd zonder dat sprake is van het opnemen van vakantie of niet werken door ziekte. ${ }^{71}$ Dit lijkt helder, maar is het niet. Hoe te handelen bij de wens tot schorsen, bijvoorbeeld hangende onderzoek naar bepaalde zaken? Moet de topfunctionaris dan in rechte tewerkstelling vorderen op straffe van het risico dat de doorlopende bezoldiging later onverschuldigd blijkt te zijn? Ik vermoed dat dit niet nodig is. Er is immers geen sprake van een omzeilen van de WNT en geen overeenkomst omtrent het beëindigen van de taakstelling. ${ }^{72}$ Het feit dat de WNT geen verband legt met artikel 7:628 BW sterkt mij in mijn opvatting. Zonder deal geldt de regel dat bij een schorsing of op nonactiefstelling de werkgever steevast moet doorbetalen. ${ }^{73}$ Maar wat is rechtens indien partijen na een paar maanden van schorsing van de topfunctionaris (die de rechtmatigheid daarvan bestrijdt, zij het niet in rechte) besluiten dat het verstandig is de relatie tot een einde te brengen en daarover een regeling willen treffen? Vanaf welk moment telt de slotzin van artikel 1.6 lid 3? Moet de topfunctionaris bovendien weer voor een week of wat aan de slag indien men het dienstverband op het moment van het bereiken van overeenstemming over de vertrekregeling niet op stel en sprong tot een einde brengt? Het lijkt me niet te veel gevraagd dat de wetgever in het kader van de behandeling van de aangekondigde aanpassingswet enige casusposities (het is geen grote moeite er nog wat meer uit de losse pols uit te tekenen, denk bijvoorbeeld aan situatief getinte arbeidsongeschiktheden) de revue laat passeren. Daarvoor is eens te meer aanleiding nu zonder zekerheid over de juiste denkrichting partijen het zekere voor het onzekere zullen nemen en daardoor eerder en langduriger in procedures verzeild raken (de mens lijdt immers meer door het lijden dat hij vreest). De beklemming die daarvan uitgaat is zelden in het belang van de betrokken instelling.

69 Kamerstukken II 2011/12, 32 600, nr. 14.

70 Kamerstukken II 2010/11, 32 600, nr. 3, p. 47.

71 Kamerstukken II 2010/11, 32 600, nr. 3, p. 42.

72 Denk aan de casus van Hof Den Haag 10 januari 2012, JAR 2012/50 (Albayrak/COA).

73 HR 21 maart 2003, JAR 2003/91 (Van der Gulik), met commentaar van S.F. Sagel, Recht op loon tijdens schorsing en op nonactiefstelling?, ArbeidsRecht 2003/6/7, p. 29. 
Het zevende en laatste advies van de commissie-Dijkstal van mei 2009 stelde dat het niet zo mag zijn dat een ontslagvergoeding het karakter van een regeling of recht krijgt toegemeten bovenop een werkloosheidsuitkering. De commissie koos als vertrekpunt dat in de hoogte van de bezoldiging van een bestuurder de compensatie voor het risico op ontslag al is verdisconteerd. Een vergoeding zou pas dan gerechtvaardigd zijn als er sprake was van onvrijwillig ontslag (dus niet bij einde van de aanstellingsperiode ${ }^{74}$ ). Het wetsontwerp nam dit advies bij nader inzien niet over, nu een verbod op een ontslaguitkering anders dan bij onvrijwillig ontslag niet handhaafbaar zou zijn. Wel kwam de regering wegens het ontbreken van een prikkel en het feit dat de beëindiging van de aanstelling of arbeidsovereenkomst voorzienbaar was, tot het oordeel dat een ontslagvergoeding van een jaarsalaris nog te hoog was. De regering zag hierin aanleiding de ontslagvergoeding verder te beperken tot ten hoogste $€ 75.000 .^{75}$

Het wetsontwerp zag af van uitzonderingen op deze regel om te voorkomen 'dat met het opnemen van een lijst van gronden voor afwijking het risico op ontduiking van de wet wordt vergroot'. De MvT voegde eraan toe dat het niet wettelijk regelen van deze gronden voor afwijking onverlet laat dat partijen kunnen besluiten achteraf de eventuele onrechtmatigheid van het ontslag en de vergoeding van de door die onrechtmatigheid geleden schade voor te leggen aan een rechter. ${ }^{76}$ In de nota naar aanleiding van het verslag werd hierover opgemerkt dat dit geen vluchtroute vormde. Er was slechts bedoeld te zeggen dat de wettelijke beperking van een overeen te komen ontslaguitkering niet afdoet aan de mogelijkheid die de wet al biedt voor een schadevergoeding bij onrechtmatig ontslag. Dan is de daadwerkelijk geleden schade de maatstaf voor een vergoeding en niet een overeenkomst tussen werkgever en werknemer. ${ }^{77}$ Deze passage toont dat de wetgever zelf het spoor van het complexe civielrechtelijke ontslagrecht in ons land enigszins kwijt is. De door de ontbindingsrechter in het kader van een ontbindingsverzoek op grond van artikel 7:685 BW toe te kennen vergoeding betreft een billijkheidsvergoeding. Het gaat daarbij niet om een schadevergoeding voor de daadwerkelijk geleden schade. Zo constateerde de ontbindingsrechter te Arnhem in een beschikking van 4 december 2012 dat artikel 2.10 WNT slechts bepaalt dat partijen geen hogere vergoeding overeen mogen komen en de kantonrechter derhalve vrij laat in zijn oordeel. De ontbindingsrechter kende aan de directeur een vergoeding toe van $€ 175.000$ bruto $(C=1)$. Hij wees de gedachte van een reflexwerking van de WNT af, ook gelet op het feit dat de betrokken topfunctionaris gedeeltelijk arbeidsongeschikt was. ${ }^{78}$ De ontslagvergoeding wegens kennelijk onredelijke opzegging is wel een schadevergoeding, maar heeft krachtens de bekende Rutten/ in werking was getreden, dan wel een gevolg was van het feit dat de WNT in art. 2.10 de rechter geen beperking oplegt, of beide. 
Breed-jurisprudentie toch ook een zeker 'pleister op de wonde'-gehalte. ${ }^{79}$ Ook in het ambtenarenrecht geldt overigens op grond van vaste rechtspraak dat een schadevergoeding bij ontslag wegens verstoorde verhoudingen geen volledige schadevergoeding is, maar - naast de geldende uitkeringsregeling - slechts compensatie biedt voor het aandeel dat het bestuursorgaan heeft gehad in het ontstaan en voortbestaan van de situatie die tot het ontslag heeft geleid. ${ }^{80}$

De WNT laat de rechter inderdaad vrij in zijn oordeel over een ontslagvergoeding. Dit geldt zowel voor de bestuursrechter in een ambtelijke omgeving als voor de '681'- en '685'-rechters in het civielrechtelijke arbeidsrecht. Er valt evenwel iets af te dingen op de gedachte dat het er in de WNT (slechts) om gaat dat partijen geen hogere vergoeding overeen mogen komen. Artikel 1.6 lid 2 bepaalt dat voor zover partijen een hogere uitkering wegens beëindiging van het dienstverband overeenkomen dan bij of krachtens de WNT is toegestaan, de uitkering van rechtswege het bedrag vormt dat ten hoogste is toegestaan. Betalingen die dit bedrag overschrijden, zijn onverschuldigd betaald, tenzij de betaling voortvloeit uit een rechterlijke uitspraak (zoals de Arnhemse '685'-beschikking). De duiding van onverschuldigde betaling betekent dat de ontvanger van de uitkering nooit eigendom verkrijgt. Dit geldt zowel voor de betaling krachtens afspraak als bij een betaling die zonder afspraak hoger is dan toegestaan. Men kan de WNT niet ontduiken door betalingen te verrichten die niet zijn overeengekomen. De verantwoordelijke kan steeds terugvorderen. ${ }^{81}$ Voor zover u nog twijfelde: ieder beding tussen partijen houdende kwijtschelding van een onverschuldigde betaling of een schenking die met de onverschuldigde betaling wordt verrekend, is nietig (art. 1.6 lid 5). Alleen de rechter is vrij in zijn oordeel, en de door hem bepaalde ontslagvergoeding is niet onverschuldigd betaald. De WNT stelt immers: 'tenzij de betaling voortvloeit uit een rechterlijke uitspraak'. Het luistert nauw.

Bij het 'tenzij de betaling voortvloeit uit een rechterlijke uitspraak' dacht de wetgever aan uitspraken op tegenspraak. Ik vermoed dat voor veel lezers de formele ontbindingspraktijk nog vers in het geheugen ligt (de genadeslag viel eerst per 1 januari $2013^{82}$ ). Ik denk niet dat de WNT die praktijk in haar zuivere vorm voor de topfunctionaris weer tot bloei brengt. Goed verdedigbaar is immers dat voor de toepassing van de WNT de betaling van een in een formele ontbindingsbeschikking vastgelegde vergoeding niet, althans niet alleen, voortvloeit uit een rechterlijke uitspraak, maar verband houdt met de vertrekregeling waarvan de formele ontbindingsprocedure een uitvoeringshandeling vormt. De formele ontbindingsbeschikking is aldus in mijn visie geen toverstokje dat onverschuldigd

79 HR 12 februari 2010, JAR 2010/72 en NJ 2010, 494 m.nt. Heerma van Voss (Rutten/Breed).

80 CRvB 7 oktober 2010, TAR 2010/175. Zie voorts de in noot 84 hierna genoemde jurisprudentie.

81 Kamerstukken II 2010/11, 32 600, nr. 3, p. 42.

82 Bij de na 1 januari 2013 ingediende '685'-verzoeken wordt niet langer een maand korting op de fictieve opzegtermijn toegepast. De tekst van het tot 1 januari 2013 geldende art. 16 lid 3 WW is overgebracht naar art. 2 Gelijkstellingsregeling arbeidsuren, en dit zonder de kortingsregeling. Zie de Wet vereenvoudiging regelingen WW, Stb. 2012, 675 en de Gelijkstellingsregeling arbeidsuren, 20 december 2012, Stcrt. 2012, 26779. Zie het commentaar van G.C. Boot, Wet vereenvoudiging regelingen UWV: over de fictieve opzegtermijn en de WW als trampoline naar ander werk, ArbeidsRecht 2013/2, p. 11. 
verandert in verschuldigd. Daarmee zijn we er echter nog niet. Tussen een formeel gevoerde en een inhoudelijk gevoerde ontbindingsprocedure op grond van artikel 7:685 BW zit een grijs gebied. Veel inhoudelijk gestarte ontbindingsprocedures worden voorts tijdens of rondom de mondelinge behandeling, vaak op initiatief van de rechter, alsnog geregeld. Maakt de WNT hier ook een einde aan? Ik vermoed dat dit niet het geval is. Men treft ter zitting geen regeling, maar legt zich in diezelfde zitting (jazeker, tandenknarsend en met geweeklaag en aldus met gepaste schoorvoetendheid) neer bij het oordeel van de ontbindingsrechter omtrent de (hoogte van de) ontbindingsvergoeding en regelt vervolgens de andere modaliteiten van het vertrek binnen de WNT-normen (uiteraard, gelet op art. 1.6 lid 3, geen ontbinding op termijn). Zal de ontbindingsrechter bereid zijn in voorkomend geval (actief) mee te werken aan een dergelijke modus operandi (zijn rechterlijke uitspraak moet de exit WNT-proof maken)? Ik vermoed dat velen die medewerking verlenen, alleen al uit valabele overwegingen van werkdruk. Wie hierbij denkt in termen van het opvoeren van toneelstukjes vergist zich in de rijkheid van de schakeringen van de ervaren realiteit en vergeet dat het niet willen horen, zien of spreken van een zich neerleggen bij een bepaald aanvaardbaar geacht bedrag aan ontslagvergoeding (uiteraard goed gemotiveerd vast te leggen in de ontbindingsbeschikking) ook - en soms misschien: juist - aanzet tot het opvoeren van toneelstukjes. Daar komt nog bij dat het effect van de ontsnappingsclausule van het 'tenzij de betaling voortvloeit uit een rechterlijke uitspraak' wel eens tot gevolg zal kunnen hebben dat topfunctionarissen schikkingen uit de weg gaan. Dit geldt zeker indien een bedrag van $€ 75.000$ sterk neerwaarts afwijkt van de 'normale' kantonrechtersformule (onder het motto: 'neen $=75$ mille, en dat heb je, ja = meer en dat kun je potentieel krijgen').

Hoe zit het met wachtgeldregelingen en de wettelijke en eventuele bovenwettelijke uitkering ingevolge de Werkloosheidswet (WW)? De WNT laat deze regelingen en uitkeringen buiten beschouwing. Het betreft immers 'uitkeringen die voortvloeien uit een algemeen verbindend verklaarde collectieve arbeidsovereenkomst of een wettelijk voorschrift'. Het gaat dus niet om een uitkering wegens beëindiging van het dienstverband in de zin van de WNT. De Brochure 'Wat betekent de WNT voor ú?' stelt terecht en onomwonden dat het bovenwettelijke deel van de WW-uitkering losstaat van de ontslagvergoeding en hier niet in meetelt. ${ }^{83}$ Dat betekent naar mijn overtuiging dat ook een afkoop van dergelijke uitkerings-

83 Hoezeer ook buiten WNT-verband uit de jurisprudentie rondom ontslagkwesties en de te betalen ontslagvergoeding blijkt dat het bestaan van een bovenwettelijke wachtgeld-/WW-regeling invloed heeft op de vraag of de werkgever een ontslagvergoeding moet betalen en zo ja hoeveel. Zie voor de private sector Ktr. Nijmegen 23 mei 1997, JAR 1997/145; Ktr. Rotterdam (JAR refereert ten onrechte aan Sommelsdijk, zie rectificatie p. 966) 18 juli 1997, JAR 1997/171; Ktr. Utrecht 29 augustus 1997, JAR 1997/205; Ktr. Utrecht 23 april 1999, JAR 1999/134; Ktr. Amsterdam 1 februari 2007, JAR 2007/75; Ktr. Deventer 6 augustus 2007, JAR 2007/217; Ktr. Amsterdam 21 januari 2008, JAR 2008/43; Hof Amsterdam 15 maart 2011, JAR 2011/105. Zie voor de publieke sector, vooral ten aanzien van het ontslag op andere gronden, de vaste lijn in de rechtspraak in CRvB 23 mei 2001, TAR 2001/122; CRvB 7 april 2009, TAR 2009/142; CRvB 7 oktober 2010, TAR 2010/175; CRvB 9 december 2010, TAR 2011/93; CRvB 15 maart 2012, TAR 2012/111; CRvB 19 april 2012, TAR 2012/138; CRvB 10 mei 2012, TAR 2012/151; CRvB 2 augustus 2012, TAR 2012/178; CRvB 28 februari 2013, LJN BZ2044. 
rechten buiten het bereik van de WNT blijft. Indien de onderliggende waarde buiten schot blijft, geldt dat ook voor het (be)schikken over die waarde. Het is opmerkelijk dat het wetgevingsproces hier geen woord aan besteedt. Op de ambtelijke ontslagvelden is het niet ongebruikelijk dat partijen in het kader van een vertrekregeling een afspraak maken over een afkoop van wachtgeld/WW-rechten tegen percentages die, zo begrijp ik, veelal liggen in de orde van grootte van $30-40 \%$ van de onderliggende maximale uitkeringswaarde. Sommige rechtspositieregelingen bevatten tekst over deze afkoopmogelijkheid. ${ }^{84}$ De WNT maakt duidelijk dat een surplus bovenop de afkoop onderworpen is aan de grens van een jaar/75 mille. Maar wat is een surplus en wat is nog afkoop? Kan men, met andere woorden, door te kiezen voor een hoger afkooppercentage (stel: 50\%) langer onder de WNT-radar blijven? Ik meen dat dit het gebied wel erg veel grijze tinten geeft. Het is zonder duidelijke richtlijnen voor de controlerende accountant erg lastig te bepalen in welke situatie nog sprake is van een afkoop van de bovenwettelijke WW-uitkering en waar men begint met het tellen voor het onder de WNT vallende surplus. De WNT legt het gebruik van de afkoop van rechten niet aan banden. Wat te denken van het geval dat een topfunctionaris snel en voorspoedig na een ontslag weer een baan vindt, maar intussen wel voor een fors bedrag (ver boven de jaarlijkse beloning) aan afkoop van wachtgeld heeft getoucheerd? Voor de betrokken instelling was de deal interessant, nu men als eigenrisicodrager het risico van een aanzienlijke uitkeringsperiode wist te ecarteren. Wie enig wantrouwen koestert ten aanzien van de bereidheid elkaar tegemoet te komen, zou hier waarschijnlijk nog wat extra duimschroeven in de WNT hebben versleuteld.

Hoewel de tekst van artikel 7.3 anders lijkt aan te geven, is de overgangsrechtelijke afbouwregeling van drie jaar niet van toepassing op de uitkering wegens beëindiging van het dienstverband. Deze tekstuele onduidelijkheid zal in de aangekondigde aanpassingswet worden weggenomen. ${ }^{85}$

\subsection{Handhaving}

De WNT vergt enige inspanning, brengt extra kosten mee. De betrokken rechtspersonen en instellingen moeten een door een externe accountant gecontroleerd financieel verslaggevingsdocument (als begrip geïntroduceerd in art. 1.1 onderdeel j) opstellen. Dit document moet de in artikel 4.1 en artikel 4.2 voorgeschreven gegevens bevatten. Het document moet worden gezonden aan het betrokken ministerie, dat vervolgens de verstrekte gegevens openbaar maakt. ${ }^{86}$ De accountant heeft tot taak onverschuldigde betalingen aan de betrokken minister te melden indien een vordering op een (gewezen) topfunctionaris uit onverschuldigde betaling niet in het genoemde document is opgenomen of ten tijde van de con-

84 Zie bijvoorbeeld M.J. Oudenhuijsen, De ambtenaar is bij ontslag vaak slechter af dan de civiele werknemer, ArbeidsRecht 2012/11, p. 49. De auteur geeft het voorbeeld van art. 16 Besluit bovenwettelijke werkloosheidsuitkering van de politie: 'Het recht op de bovenwettelijke uitkering kan op aanvraag van de betrokkene worden afgekocht tegen $30 \%$ van de nominale waarde.'

85 Kamerstukken I 2011/12, 32 600, nr. F, p. 27.

86 Het punt trad naar voren bij de behandeling van de ANBI's: brengt men deze allemaal onder de WNT, dan is de consequentie dat circa 65.000 instellingen, waaronder 25.000 kerken, de desbetreffende kosten moeten maken en op de in de WNT bedoelde publieke tribune terechtkomen. 
trole nog niet is terugbetaald (art. 5.2). De betrokken minister maakt de gegevens openbaar die ten onrechte niet door de verantwoordelijken in het financieel verslaggevingsdocument zijn opgenomen (art. 5.6 lid 1). De externe accountants zijn aldus de door de instellingen bezoldigde politieagenten van de WNT.

De WNT heeft gekozen voor (bestuursrechtelijke) herstelsancties ten faveure van strafsancties. Dit voorkomt dat te betalen boetes ten koste gaan van de uitvoering van de publieke taken. Het gaat er voorts om de betrokken spelers aan te zetten tot gedrag dat in overeenstemming is met het doel van de WNT. Uitgangspunt van een herstelsanctie is het beëindigen van een overtreding, het voorkomen van herhaling of het wegnemen of beperken van de gevolgen van een overtreding. Hoger dan toegestane bezoldigingen zijn van rechtswege onverschuldigd betaald. Deze terugbetalingsplicht geldt ook voor inmiddels aan de Belastingdienst of het pensioenfonds betaalde afdrachten. De wettelijke definitie van betaling in artikel 1.1 onderdeel $\mathrm{k}$ stelt buiten twijfel dat een afdracht aan de fiscus, aan het pensioenfonds of aan een derde (denk aan de betaling aan een management-bv) als betaling aan de topfunctionaris heeft te gelden. Het is aan deze functionaris om in de sfeer van de inkomstenbelasting de over de onverschuldigde betaling betaalde belasting terug te krijgen. ${ }^{87}$

De betrokken minister heeft op grond van de WNT de bevoegdheid door middel van een last onder dwangsom zowel de instelling (de werkgever) als de werknemer te bewegen gemaakte bezoldigingsafspraken die niet voldoen aan de wet te herzien en, mocht men geen adequate actie ondernemen, verboden betalingen in het uiterste geval daadwerkelijk zelf via een besluit tot opeisen te ontnemen. ${ }^{88} \mathrm{De}$ last onder dwangsom wordt door plaatsing in de Staatscourant openbaar gemaakt (art. 5.4 lid 2). Voorafgaand aan het opleggen van een last onder dwangsom zal de minister eerst partijen in de gelegenheid stellen de overtreding binnen een bepaalde termijn ongedaan te maken door de gemaakte bezoldigingsafspraken te herzien en te hoge betalingen terug te draaien. Een dergelijke 'waarschuwing' is in de visie van de wetgever gebruikelijk bij handhavingsbesluiten en hoefde daarom niet apart te worden geregeld. ${ }^{89}$ Pas als partijen niet zelf de overtredingen beëindigen, zal de minister een handhavingsbesluit nemen. Bij het voorbereiden van een last zal de minister op de voet van het bepaalde in artikel 4:8 van de Algemene wet bestuursrecht de belanghebbenden in de gelegenheid stellen zich over het voorgenomen besluit (het besluit tot opeisen) uit te laten. We zagen al dat een kwijtschelding of een schenking geen roet in dit eten van de minister kan gooien. Een dergelijke afspraak is nietig (art. 1.6 lid 5). Met de bekendmaking van het besluit tot opeisen vervalt de vordering van de instelling zelf uit onverschuldigde betaling. De opgeëiste bedragen komen toe aan de Staat (art. 5.5 lid 1). Deze regeling vormt een eigentijdse variant op het thema van de premiejager. Doet de instelling niets, dan verliest zij haar recht van spreken en de revenuen van een aan de werkgever geretourneerde onverschuldigde betaling waarover reeds loonbelasting is geheven, op grond van vaste jurisprudentie wordt aangemerkt als negatief inkomen. 
succesvolle terugvorderingsactie. Doet de instelling niets, dan baat dit de topfunctionaris niet. De WNT 'gunt' in dit geval het recht tot vorderen en de revenuen aan de Staat. Die weet er ongetwijfeld raad mee. Verwacht niet dat het bedrag wordt geretourneerd aan de werkgever. Bij restitutie staat onvoldoende vast dat de overtreding wordt gestaakt. In de woorden van de MvT: 'De effectiviteit van het instrument rechtvaardigt dat de opgeëiste bedragen niet aan de betrokken instelling worden gerestitueerd, waarbij mede wordt gelet op de omstandigheid dat de instelling iedere gelegenheid voorbij heeft laten gaan de desbetreffende bedragen terug te vorderen en aan te wenden voor de uitvoering van haar wettelijke taak. Zij heeft daarmee als het ware afstand gedaan van deze financiële middelen. ${ }^{90}$

\subsection{Het adviescollege normeringsbeleid bezoldigingen topfunctionarissen}

De WNT introduceert een onafhankelijk adviescollege dat eenmaal per vier jaar (de eerste evaluatie valt evenwel reeds na twee jaar) een advies aan de regering uitbrengt over het bezoldigingsbeleid van topfunctionarissen in de publieke en semipublieke sector. De wijze van benoeming van zijn leden vloeit voort uit hetgeen is voorzien in (art. 11 van) de Kaderwet adviescolleges. Dit adviescollege krijgt tevens de opdracht te rapporteren over de verbetering en de effectiviteit van de wet. Dat betreft mede het gebruik van ontduikings- en ontwijkingsmogelijkheden. ${ }^{91}$ Voorts dient dit college de te verwachten 'verhalen' van instellingen dat men vanwege de WNT niet in voldoende mate deskundigen kan aantrekken, in perspectief te plaatsen en zo hanteerbaar te houden. ${ }^{92}$

\subsection{Het overgangsrecht}

De MvT brengt tot uitdrukking dat de wens bestond het normenkader toe te passen op bestaande gevallen, die immers mede aanleiding waren dat normenkader in te voeren. Anderzijds diende de wet rekening te houden met het door artikel 1 Eerste Protocol bij het EVRM vastgelegde grondrecht op de bescherming van het recht op het ongestoorde genot van eigendom. De WNT vormde een inmenging op dat eigendomsrecht. De te stellen eisen zijn: een wettelijke basis, een algemeen belang en een fair balance. Het door het kabinet ingewonnen advies van de Universiteit Leiden (als bijlage gevoegd bij de MvT) concludeerde dat aan de eerste twee eisen werd voldaan, maar dat de toepassing op bestaande overeenkomsten zonder enige vorm van overgangsrecht kwetsbaar was en waarschijnlijk niet voldeed aan de eis van een fair balance. De Leidse onderzoekers adviseerden de bezoldigingsnormen in beginsel alleen van toepassing te doen zijn op contracten en aanstellingsbesluiten die tot stand kwamen na inwerkingtreding van de WNT. De MvT koos voor een overgangsregime waarbij voor op het tijdstip van inwerkingtreding bestaande overeenkomsten een hogere bezoldiging werd toegestaan dan

90 Kamerstukken II 2010/11, 32 600, nr. 3, p. 53. De vordering verjaart vijf jaar nadat de schuldeiser met zowel het bestaan van de vordering als de persoon van de ontvanger bekend is geworden, en in ieder geval twintig jaar nadat de vordering is ontstaan. Het opleggen van een last onder dwangsom of het doen van een desbetreffende mededeling stuit de verjaring (art. 5.5 lid 4).

91 Kamerstukken II 2011/12, 32 600, nr. 27, p. 1 en 15.

92 Handelingen II 12 oktober 2011, p. 11-2-9. 
de normen van artikel 2.2 of artikel 3.2, als deze bezoldiging voorafgaand aan de inwerkingtreding van de wet was overeengekomen. Deze hogere bezoldiging mocht alleen worden verhoogd als de wijze van verhoging eveneens voorafgaand aan de inwerkingtreding van de wet was overeengekomen. Voorts werd voorgesteld dat als de WNT later op een rechtspersoon of instelling van toepassing zou worden door wijziging van de bijlage bij artikel 1.3 of artikel 1.4, sprake zou zijn van eerbiediging van overeenkomsten die waren afgesloten voorafgaand aan de inwerkingtreding van de wijziging. Dit laatste speelde uiteraard niet bij een wijziging van technische aard (denk bijvoorbeeld aan een naamswijziging van de betrokken instelling). ${ }^{93}$ Bij een neerwaartse bijstelling van het maximum of indeling in een klasse met een lagere norm zou gelden dat indien het lagere bedrag minder is dan de bezoldiging op grond van een op het moment van in werking treden van de wet (of de wijziging van de bijlage) reeds gesloten overeenkomst, de op grond van die overeenkomst geldende bezoldiging het maximum is. Maatgevend was of partijen bij het sluiten van de overeenkomst wisten dat de desbetreffende minister bevoegd was de norm te verlagen of de instellingen in te delen in klassen.

Denkbaar is dat op een instelling een indeling in klassen van toepassing is en dat na verloop van tijd de instelling in een lagere klasse geraakt zonder dat de criteria een wijziging ondergaan. De MvT vermeldt het voorbeeld van de school die door een terugloop van het aantal leerlingen in een lagere klasse terechtkomt. In dat geval daalt het toepasselijke maximum voor de zittende topfunctionarissen van rechtswege, tenzij op grond van het overgangsrecht de betrokken functionaris een hogere bezoldiging was overeengekomen voorafgaand aan de inwerkingtreding van het wetsvoorstel (bij een instelling die later op de bijlage bij artikel 3.1 of artikel 4.1 is opgenomen, geldt hetzelfde voor overeenkomsten die voorafgaand aan de opname op die bijlage zijn gesloten). ${ }^{94}$ In de samenvatting van de nota naar aanleiding van het verslag: 'De eerbiedigende werking strekt zich uit tot afspraken die zijn gemaakt voorafgaand aan inwerkingtreding van de wet of voorafgaand aan het van toepassing worden van de wet op de betreffende instelling, maar niet op afspraken die nadien zijn gemaakt, ook niet als die afspraken in strijd komen met later vastgestelde aanvullende normen, omdat met de mogelijkheid van die aanvullende normen rekening had kunnen worden gehouden.' $95 \mathrm{Ik}$ vermoed dat de wetgever zich realiseert dat aldus de schooldirecteur die een daling van het aantal scholieren voorziet (met navenante nadelige consequenties voor zijn inkomen), een financiële prikkel in de schoot geworpen krijgt om de doelgroep (ouders van potentiële instromers) extra te stimuleren bij de schoolkeuze van en voor hun kinderen. Het zou maar zo de handelsgeest van de betrokken directeur kunnen bevorderen. Wellicht is dat ook de bedoeling, maar ik geloof zelf toch minder in de zegeningen van aanzetten tot handel in schoolkeuzes.

Tijdens het wetgevingsproces werd het overgangsrecht door de regering heroverwogen. Het resultaat valt te lezen in de Derde nota van wijziging van 10 oktober 
2011. De vrees bestond dat partijen zouden voorsorteren en met name door omzetting van dienstverbanden voor bepaalde tijd in die van onbepaalde tijd met langjarige afspraken over de hoogte van de bezoldiging een uitzonderingssituatie konden handhaven. Dat was ongerijmd: degenen wier gedrag tot het wetsvoorstel had geleid, zouden voor onbepaalde tijd van de gevolgen zijn gevrijwaard. De regering stelde aldus voor de eerbiedigende werking van het overgangsrecht te beperken tot vijf jaar na inwerkingtreding van de wet of tot vijf jaar nadat de desbetreffende instelling was toegevoegd aan de bijlage bij de wet. $\mathrm{Na}$ afloop van die periode van vijf jaar volgde een afbouw van de bezoldiging over een periode van drie jaar tot het op grond van de wet geldende maximum. De periode van vijf jaar gaf voldoende tijd zich in te stellen op de nieuwe financiële situatie en eventueel een andere functie te zoeken. ${ }^{96}$ De regering constateerde dat dit overgangsrecht gelet op het advies van de Universiteit Leiden, gevoegd bij de MvT, ieder risico van strijd met artikel 1 Eerste Protocol bij het EVRM uitsloot. ${ }^{97}$ Voorts bepaalde een nieuw lid van artikel 7.3 (uiteindelijk vernummerd tot artikel 7.3 lid 10) dat wijzigingen in het dienstverband of de bezoldiging tussen het moment van aanvaarding van het wetsvoorstel door de Tweede Kamer (dit werd 6 december 2011) en het moment dat de wet van kracht werd, geen aanspraak op het overgangsrecht gaven. ${ }^{98}$

In een brief aan de Tweede Kamer van 8 november 2011 drukte de minister zich iets voorzichtiger uit omtrent de verhouding tot artikel 1 Eerste Protocol. Het betrof een inschatting. Deze uitlating hield verband met de redenering achter de keuze van een overgangstermijn van vijf jaar met een afbouw van nog eens drie jaar. Het ging om het garanderen van bestaande rechten gedurende enige tijd. Daarom koos het kabinet voor vijf jaar, mede gelet op de duur van de meeste benoemingen van topfunctionarissen, die rond de vier jaar lag. De fair balance zou nog kunnen worden verstoord als bij wijze van spreken een bezoldiging na vijf jaar in één keer werd gehalveerd. Een vorm van afbouw moest dit punt adresseren. ${ }^{99}$

De Tweede Kamer nam uiteindelijk een amendement aan waarbij de voorgestelde periode van vijf jaar tot vier jaar werd teruggebracht. De afbouwperiode van drie

96 De leer van de eenzijdige wijziging van arbeidsvoorwaarden uit het Stoof/Mammoet-arrest van 2008 (HR 11 juli 2008, JAR 2008/204 en NJ 2011, 185 m.nt. Heerma van Voss) speelt geen rol. Het gaat niet om een door de werkgever gewenste wijziging, maar om een door de wetgever vastgestelde normering. In dezelfde zin Beltzer in zijn annotatie bij Rb. Den Haag (vzr.) 11 januari 2013, LJN BY8165 (NVZD/Staat) in AR Updates, AR_2013_0024. Grapperhaus liet zich over het aspect van de fair balance kritisch uit, maar ging in zijn bijdrage nog uit van een 'per direct' ingrijpen in bestaande arbeidsovereenkomsten. Zie Grapperhaus 2012, p. 13. Er is met het in de WNT gekozen overgangsrecht geen sprake van een per direct ingrijpen.

97 Kamerstukken II 2011/12, 32 600, nr. 17.

98 Zie over dit punt Burgers 2012. Vgl ook het voorbeeld genoemd in Kamerstukken I 2011/12, 32 600, nr. F, p. 25.

99 Kamerstukken II 2011/12, 32 600, nr. 27, p. 3. 
jaar bleef evenwel behouden (art. 7.3 lid 8 beschrijft de te hanteren staffeling) ${ }^{100}$ $\mathrm{Na}$ in totaal zeven jaar is de WNT dus onverkort van toepassing op iedere topfunctionaris die niet eerder bij herbenoeming of anderszins nieuwe bezoldigingsafspraken heeft gemaakt in overeenstemming met de WNT.

Met de afbouwregeling strijdige afspraken zijn nietig. De WNT wijzigt zulke afspraken overeenkomstig de afbouwregeling. Het overgangsrecht beslaat aldus uiteindelijk een periode van zeven jaar. ${ }^{101}$ Dit getal heeft de schijn van heiligheid en die gedachte past wonderwel bij wat men wil verstaan onder een fair balance. ${ }^{102}$ Deze visie treft men ook bij de Haagse voorzieningenrechter in zijn oordeel van 11 januari 2013 over het door de zorgbestuurders tegen de Staat der Nederlanden aangespannen kort geding omtrent hun positie in het licht van de WNT. ${ }^{103}$

Indien een overeenkomst voor bepaalde tijd is aangegaan, dient bij verlenging van die overeenkomst de bezoldiging aan het toepasselijke maximum te worden aangepast. ${ }^{104}$ Voor de zekerheid is dit nog expliciet vastgelegd in artikel 7.3 lid 9. ${ }^{105}$

\section{De WNT en het beginsel van de vrijheid van onderhandelen}

De vrijheid van onderhandelen over arbeidsvoorwaarden is een beginsel. Het Parallel Entry-arrest uit 2004 noemt het beginsel met zoveel woorden. Het desbetreffende grondrecht heeft betrekking op een groep werknemers, op de collectiviteit (zoals ook art. 28 van het Handvest van de grondrechten van de Europese Unie aangeeft), als een afgeleide van het recht op vrije vakvereniging. De vrijheid van onderhandelen is als grondrecht een recht dat toekomt aan vakbonden en niet een recht dat toekomt aan een individuele werknemer. Dit wil niet zeggen dat een individuele werknemer geen recht op onderhandelen heeft. In de zaak

100 Kamerstukken II 2011/12, 32 600, nr. 42. Vgl. nog het relaas van de minister in Handelingen II 12 oktober 2011, p. 11-2-10. Minister Donner noemde tijdens het debat in de Tweede Kamer de teruggang van vijf naar vier jaar een acceptabel compromis, Handelingen II 1 december 2011, p. 31-10-98. Zie over het thema voorts Kamerstukken I 2011/12, 32 600, nr. F, p. 24 e.v.

101 Voor bestaande contractuele afvloeiingsregelingen geldt een overgangsregeling van vier jaar, zonder afbouwperiode van drie jaar, overeenkomstig het bepaalde in art. 7.3 lid 6.

102 Zie de opvatting van de Raad van State in Kamerstukken I 2011/12, 32 600, nr. D, p. 7. Inspiratie voor de onderbouwing van besluitvorming over het overgangsrecht en de reikwijdte van art. 1 Eerste Protocol bij het EVRM - mede gelet op de beoordelingsmarge van de lidstaten - biedt de voorlichting van de Afdeling advisering van de Raad van State van 3 juli 2012 omtrent de kaders bij de keuze voor en de minimale vereisten bij de vormgeving van overgangsrecht op het moment dat er sprake is van wijziging van aanspraken in de socialezekerheidswetgeving dan wel de pensioenwetgeving ten nadele van uitkeringsgerechtigden dan wel potentiële uitkeringsgerechtigden. Advies W12.12.0147/III, Kamerstukken II 2012/13, 33 400-XV, nr. 7. Zie in dit verband nog Rb. Zeeland-West-Brabant 14 februari 2013, LJN BZ1292 over het ontnemen van een aanspraak waarvan de verwachting van realisering gerechtvaardigd is (het betrof de verschuiving van de ingangsdatum van de AOW van de eerste van de maand waarin men 65 wordt naar de datum van de verjaardag).

103 Rb. Den Haag (vzr.) 11 januari 2013, LJN BY8165 (NVZD/Staat) m.nt. Beltzer in AR Updates, AR_2013_0024.

104 Kamerstukken II 2010/11, 32 600, nr. 8, p. 27.

105 Kamerstukken II 2011/12, 32 600, nr. 14. 
Parallel Entry ervaart de Hoge Raad dit recht in individuele situaties (kennelijk) als een 'gewoon' recht dat geregeerd wordt door het algemeen privaatrecht en voor wat betreft de arbeidsovereenkomst in titel 10 van Boek 7 BW. ${ }^{106}$

Toch valt in mijn visie iets te zeggen voor het standpunt dat de contractsvrijheid een civielrechtelijk beginsel is van een waarde die met die van de wel in de Grondwet of internationale verdragen gepositiveerde grond- en mensenrechten vergelijkbaar is. ${ }^{107}$ Aan de zijde van de werknemer is de vrijheid om te contracteren met wie men wil in ieder geval een grondrecht. ${ }^{108}$ In de WNT is dit recht niet in het geding, zoals ook blijkt uit het feit dat de WNT geen strobreed in de weg legt aan inleningsconstructies. Het gaat slechts om de vraag over de vrijheid om inhoudelijk te contracteren zoals men wil. Die vrijheid is echter beperkt tot de grenzen die uit wet- en regelgeving voortvloeien. In het arbeidsrecht met zijn vele dwingende, driekwartdwingende en semidwingende bepalingen ${ }^{109}$ is dit reeds zonder de WNT een makkelijk herkenbaar gegeven. De WNT voegt aan de reeds bestaande regelgeving 'slechts' nog enige grenzen toe. De Haagse voorzieningenrechter had op 11 januari 2013 in het door de NVZD aangespannen kort geding niet zonder goede grond weinig moeite met het argument en overwoog kort dat (ook) artikel 11 EVRM geen plicht bevat tot onderhandeling met betrokkenen alvorens een wet in formele zin wordt vastgesteld. ${ }^{110}$ Het beginsel van de contractsvrijheid moet bovendien strijden met andere zwaarwegende beginselen en noties. Grondrechten en andere beginselen werken zelden direct door in de arbeidsrelatie zonder dat zij, hoe belangrijk ook, veelal via de open norm van het goed werkgeverschap en het goed werknemerschap in een belangenafweging terechtkomen. In het arbeidsrecht is dit een open deur. ${ }^{111}$ Daar komt wellicht bij dat in de WNT de doelgroep beperkt is tot de functieniveaus aan de top, een terrein waar de deugden van de cao als machtsfactor en drager van maatschappelijk draagvlak nauwelijks hun heilzame werking hebben. ${ }^{112}$

106 HR 30 januari 2004, JAR 2004/68 (Parallel Entry). De Hoge Raad doelde in Parallel Entry op het feit dat de rechter bij een aantasting van het resultaat van cao-onderhandelingen opbokst tegen het 'uit verscheidene verdragsbepalingen voortvloeiende zwaarwegende beginsel van de vrijheid van onderhandelen over arbeidsvoorwaarden' dat meer specifiek ziet op de positie van de vakbond.

107 In de woorden van Asser/Hartkamp \& Sieburgh 2010 (6 III*), nr. 59.

108 Zie art. 19 lid 3 Grondwet en vgl. HvJ EG 16 december 1992, JAR 1993/64 (Katsikas), punten 31-33, en HvJ EG 24 januari 2002, JAR 2002/47 (Temco), punt 36.

109 Zie daarover Kamerstukken I 1999/2000, nr. 222a en A.R. Houweling \& L.J.M. Langedijk, Dwingend recht in het arbeidsovereenkomstenrecht: van confectie naar couture, ArA 2011/1, p. 9-32.

110 Rb. Den Haag (vzr.) 11 januari 2013, JAR 2013/49 m.nt. Janssen (NVZD/Staat).

111 Voor een meer omvattende beschouwing over de materie van de grondrechten in het arbeidsrecht verwijs ik naar mijn bijdrage aan de grondrechtenbundel die rond de zomer van 2013 verschijnt in de serie Onderneming en Recht (OO\&R reeks).

$112 \mathrm{Bij}$ het overleg over de te hanteren sectorale bezoldigingsnorm in het tweede regime worden de werknemersorganisaties niet betrokken. Topfunctionarissen vallen in het algemeen buiten de cao en zijn niet georganiseerd. Zie Kamerstukken I 2011/12, 32 600, nr. F, p. 14. 


\section{Het regeerakkoord 'Bruggen slaan' van 29 oktober 2012}

Het zijn van topfunctionaris in de publieke en semipublieke sector heeft iets groots. Het krijgt met het regeerakkoord van 29 oktober 2012 ook iets meeslepends. Het regeerakkoord bevat een aanscherping van het in de WNT neergelegde normeringsbeleid. ${ }^{113}$ Deze aanscherping valt bij lezing van p. 17 van het regeerakkoord nog mee. Daar staat dat de beloningen bij instellingen van hoger onderwijs in overleg met de sector versneld op orde worden gebracht. Men kan dit beschouwen als een typisch WNT-actiepunt. Dit geldt ook voor de tekst op p. 32, waar het huidige kabinet wil aansturen op een versneld aanpassen van de beloning van bestuurders van woningbouwcorporaties aan de WNT. Ook de tekst van p. 21 wekt geen beroering. Het rapport van de commissie-Meurs is leidraad bij het inkomensbeleid gericht op medisch specialisten. ${ }^{114}$ Dit rapport wijst ten aanzien van medisch specialisten rechtstreekse ingrepen in de bezoldiging of in de aard van de arbeidsrelatie af. Leest $u$ door tot p. 41, dan gaat u er even bij zitten. Het salaris van bewindspersonen wordt definitief niet verhoogd. In lijn hiermee is het de bedoeling de WNT aan te passen en de norm voor de beloning te stellen op $100 \%$ van een ministersalaris in plaats van de huidige $130 \%$ ( $€ 144.107$ in plaats van $€ 187.340$ ). Deze norm wordt in de visie van 'Bruggen slaan' niet alleen van toepassing voor topfunctionarissen, maar zal gelden voor alle medewerkers met een dienstverband (het blijft mogelijk een uitzondering te maken, indien dat noodzakelijk is). ${ }^{115}$ De WNT beperkt waarschijnlijk het inkomen van enkele honderden functionarissen. Verlaagt men de norm en betrekt men alle medewerkers bij de normering, dan is de taxatie dat dit enkele duizenden functionarissen zal raken. ${ }^{116}$ De voorgestelde aanpassing van de WNT duikt, zo is duidelijk bij lezing van p. 45, al op in de budgetten. Meestal is dit een teken dat men een bepaalde mate van doorzettingsvermogen wil etaleren. De WNT zal wellicht het einde van het begin van wettelijke ingrepen zijn en niet het begin van het einde.

113 In de woorden van de brief van de minister van Binnenlandse Zaken en Koninkrijksrelaties aan de Tweede Kamer van 13 februari 2013, kenmerk 2013-0000058635, p. 3.

114 Rapport 'Gezond belonen' van de Commissie inkomens medisch specialisten (commissie-Meurs), 10 oktober 2012.

115 Men kan wijzen op de notie van gelijke behandeling en daaraan de gedachte ontlenen dat dit een juiste opstelling vormt. Toch lijkt mij dat de WNT op dit punt niet uitglijdt, en zeker niet in het licht van het oordeel van de Hoge Raad over de materie in het Parallel Entry-arrest. De categorie 'topfunctionaris' is als groep voldoende afgebakend en wordt als zodanig in de WNT gelijk behandeld. Het regeerakkoord zal wel een 'draai' moeten geven aan het betoog dat een normering van de bezoldiging van alle functionarissen binnen de publieke en semipublieke sector niet proportioneel is, dat dan de loonvorming door de sociale partners de voorrang moet krijgen. Dit standpunt verdedigde de minister in de Eerste Kamer in het kader van de onderbouwing van de beperking van de WNT tot topfunctionarissen. Zie Kamerstukken I 2011/12, 32 600, nr. F, p. 16.

116 Handelingen I 6 november 2012, p. 6-7-28. 


\section{$5 \quad$ Ter afsluiting}

De WNT betreft een in de woorden van minister Donner vrij unieke wet voor een vrij uniek en complex probleem: hoe krijgt men de in de visie van de wetgever uit de hand gelopen ontwikkeling van de salarissen in de publieke en betrokken semipublieke sector onder controle zonder dat dit tot scheefgroei leidt? ${ }^{117}$ Het unieke karakter schuilt mede in de bij formele wet geregelde beperking van de privaatrechtelijke vrijheid van onderhandelen en contracteren. Iets unieks is ook te vinden in de lengte van de periode die de wetgever koos voor het overgangsrecht ten aanzien van bestaande situaties. ${ }^{118}$ Voor wie gewend is aan enig tempo, heeft het overgangsrecht iets van een fluwelen handschoen. Ik kan mij vinden in de gedachte dat deze handschoen de notie van een fair balance binnenboord haalt.

De wetgevingsjuristen moeten zich bij het opstellen van het wetsvoorstel hebben gevoeld als de in het arbeidsrecht geverseerde advocaat van de instelling die een vertrekregeling met een topfunctionaris moet vastleggen en alle inventiviteit en ervaring moet inzetten om te verhinderen dat er gaten in de regeling achterblijven die na ondertekening voor de werknemer de mogelijkheid bieden toch meer dan het afgesproken bedrag te vorderen. Ik realiseer mij dat deze wetgevingsjuristen juist ten aanzien van de ontslagvergoeding genoodzaakt waren terughoudend te werk te gaan. De steken die daar voor het oprapen liggen, heeft men naar ik vermoed bij volle bewustzijn laten vallen. Dat gezegd hebbend, is de WNT voor iemand die gewend is aan het afhechten van sluiproutes een plezierig leesbaar geheel. Deze routes zijn er waar je ze zou verwachten (bij de uitkering wegens de beëindiging van het dienstverband), maar voor het overige oogt de WNT verrassend robuust. Dit is geen uitnodiging tot het verkennen van de gesuggereerde speelruimte bij de uitkering wegens de beëindiging van het dienstverband. De signalen zijn betrekkelijk helder en de eerste evaluatie valt reeds over twee jaar te lezen, wat onverlet laat dat ik daadwerkelijk hoop dat de wetgever bereid is bij de behandeling van de aangekondigde aanpassingswet overeenkomstig mijn suggesties extra body te geven aan de door de wetgever beoogde contouren van die speelruimte. Het draagvlak voor de(ze) WNT bleek in ieder geval de afgelopen jaren bij de betrokken kabinetten en in de Eerste en Tweede Kamer kamerbreed. Wie om de WNT tranen laat, ziet in de spiegel toch vooral een krokodil.

117 Handelingen II 12 oktober 2011, p. 11-2-2 en p. 11-2-8.

118 Minder uniek is dat afspraken boven het WNT-niveau van na 6 december 2011 geldig waren tot 1 januari 2013 en per die datum ten aanzien van het 'bovenmatige' deel nietig zijn. De wetgever stelt op dit punt in art. 7.10 niet meer of minder dan dat overgangsrecht ontbreekt. In feite geeft de wetgever daarmee aan dat na 6 december 2011 boven het WNT-niveau uitstijgende afspraken voor het 'bovenmatige' deel nog maar voor een beperkte periode konden worden gemaakt. Het resultaat lijkt sterk op een toegestane tijdelijke toeslag, waarbij geldt dat partijen van begin af aan van de hoed en de rand wisten. Dat is niet heel bijzonder. In fiscalibus zou men deze aanpak waarschijnlijk eerder als 'soft' duiden. 